\title{
ACTION RESEARCH IN LANDSCAPE ECOLOGY (ŠUMAVA BIOSPHERE RESERVE, CZECH REPUBLIC CASE STUDY)
}

\author{
DRAHOMÍRA KUŠOVÁ ${ }^{1}$, JAN TĚŠITEL ${ }^{2,3}$
}

${ }^{1}$ Faculty of Agriculture, University of South Bohemia, Studentská 1668, CZ-37005 České Budějovice, Czech Republic; e-mail: dkusova@zf.jcu.cz

${ }^{2}$ College of Regional Development, Prague, Žalanského 68/54, CZ-16300 Praha 17 - ̌̌epy, Czech Republic; e-mail: jan.tesitel@metcenas.cz

${ }^{3}$ METCENAS, o.p.s., Tleskačova 1329/16, CZ-32300 Plzeň, Czech Republic

\begin{abstract}
Kušová D., Těšitel J.: Action research in landscape ecology (Šumava Biosphere Reserve, Czech Republic case study). Ekológia (Bratislava), Vol. 36, No. 4, p. 323-338, 2017.

Current landscape ecological research applies trans-disciplinarity as a principle when considering the study of landscape as a multifunctional entity. The principle can be practically applied by use of participatory action research. The paper reports on the use of participatory action research in the process of step-by-step institutionalization of the Šumava Biosphere Reserve, as a complement to the state-conducted nature conservation, which took place in the period 1991-2016. To briefly summarize the main findings, we can suggest that the present institutional model of the Sumava Biosphere Reserve emerged primarily thanks to the 'permanent jointly conducted experiment' that followed the spiral scheme of action research, in which outputs of one implementation project served as a starting point to formulate, and subsequently realize the follow-up projects(s). The local community was engaged in the whole process, hence lessons learned became a part of local social and cultural capital, which since can be considered important endogenous developmental potential of the region.
\end{abstract}

Key words: landscape ecology, trans-disciplinarity, action research, integrated nature conservation, Sumava Biosphere Reserve.

\section{Introduction}

Landscape ecology, since identified as a scientific discipline in late 1930s (Troll, 1939), passed through many changes, in scope and consequently, in interpretative frames (Antrop, 2006). Step by step, economic interests, social institutions and decision-making processes were recognized as important drivers of landscape dynamics and their nature as well as effects have become a subject of landscape ecological research, as important parameters of behaviour of landscape articulated in terms of multifunctional socio-ecological system (e.g. Holling et al., 2002).

As a result, trans-disciplinarity has become one of the guiding principles of recent landscape ecological research (e.g. Tress et al., 2003). It presumes, among other things, a profound 
change in the role of practice in the research - from practice being a mere subject of a research to considering practitioners as engaged members of the research team. The principle of trans-disciplinarity can be then methodologically embodied in the format of participatory action research. This research combines generation of theory with changing the social system through the researcher acting on or in the social system. The act itself is presented as the means of both changing the system and generating critical knowledge about it. It aims then to contribute both to the practical concerns of people in an immediate problematic situation and to the goals of science, by a joint collaboration within a mutually acceptable framework (e.g. Susman, Evered, 1978; Berg, 2004). Participatory action research has some qualities that distinguishes it from the classical approach (Hendl, 2008). It consciously seeks to study something in order to change or improve it. Positive social change is the predominant force driving this kind of research. The process is iterative in its nature. It is conceived as a spiral of steps, each of which is composed of a circle of planning, action taking and reflective learning (Berg, 2004). Viewed from this perspective, this research can also be considered as one introducing a change experiment into landscape ecology. Building on the presumption that social reality is socially constructed, participatory action research takes a form of an emergent process, largely controlled by local conditions (Elden, Chisholm, 1993), as can be seen on the Fig. 1.

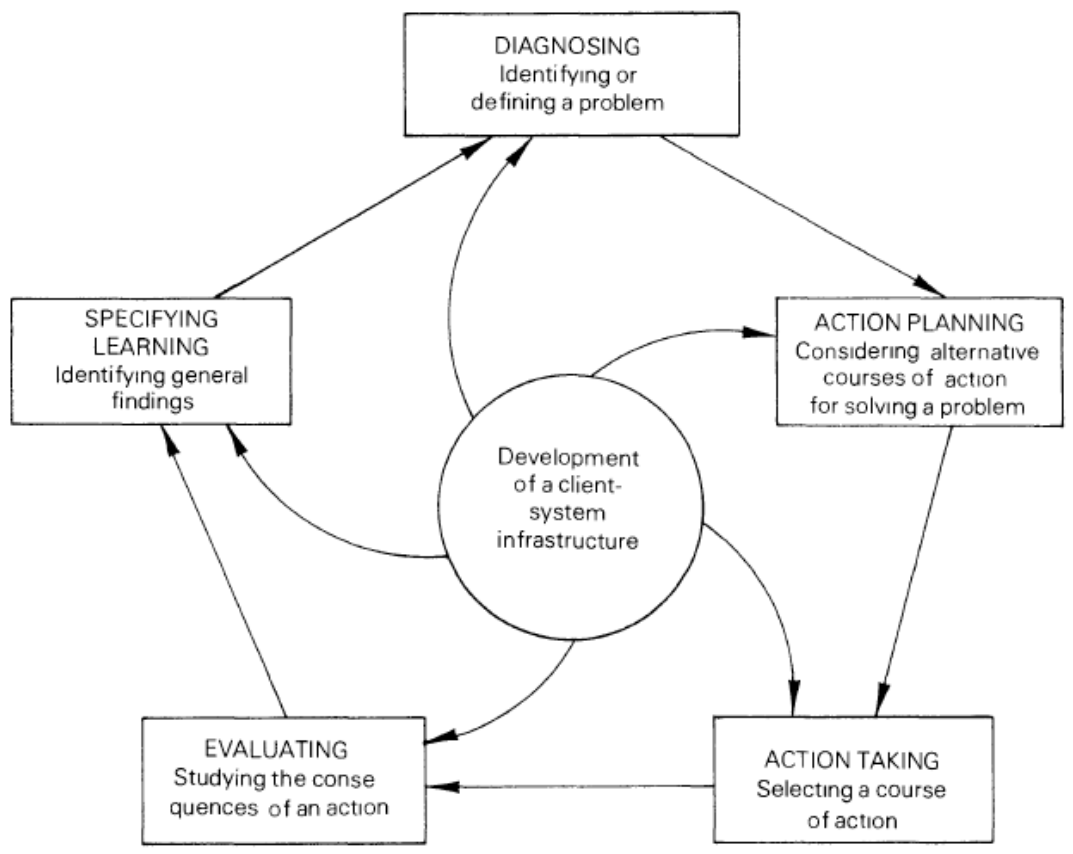

Fig. 1. The cyclical process of action research. According to Susman, Evered (1978). 
It is important then for the researcher to recognize that the issues to be studied are considered important by the stakeholders and are not simply of interest to the researcher. Consequently, problem should be formulated from the perspective of the studied population. Based on the qualities mentioned above, participatory action research appears to be a very effective way of transferring research outputs into practice, hence speeding up the introduction of desired changes. As it implicitly encompasses the process of permanent learning by acting (Lundvall, 1977), participatory action research encourages development of the selfhelp competencies of people facing the problem.

Multifunctional landscape assumes multiple perspectives and hence multiple interests of its use. Large-scale protected areas can be well used to document the challenge. Potential conflicts of interests are articulated there in a more straightforward way, compared to areas without conservation. Management of large-scale protected areas must cope with the challenge of harmonizing nature conservation interests with historically developed, locally embedded forms and practices of land-use. In a long run, we can identify two basic approaches to the management of protected areas that fundamentally differ in the extent to which local residents are integrated into decision-making processes concerning land-use (Hayes, 2006). In the traditional, exclusive model of nature conservation an approach that excludes local residents from this decisionmaking and strictly regulates their activities is preferred. It assumes nature conservation to be primarily carried out by state administration (Ghimire, Pimbert, 1997). The other, inclusive model is based on the assumption that the success of nature conservation largely depends on involvement of local residents both in the process of declaring protected areas as well as in the way they are managed. In this context, Stoll-Kleeman and O'Riordan (2002) propose a change in the paradigm towards integrated nature conservation, where the approach of rigid top-down commands is replaced by a flexible approach based on the participation of local and regional stakeholders. This participatory trend is particularly evident in Central Europe, where largescale protected areas are mostly cultural landscapes, having been transformed by humans for centuries (Paavola, Adger, 2005). Human activities are then necessary to maintain the character of these landscapes for future generations. Discussions on land-use should therefore pertain to their form, intensity and spatial distribution, rather than to elimination of human activities from the protected area. Finding a consensual economic activity, compatible with the interests of nature conservation interests, is suggested to be the most effective way to cope with this situation. Sound tourism is frequently mentioned in this context (e. g. Law et al., 2009; Becker, George, 2011; Hadwen et al., 2012; Habibah et al., 2013; Lisi, Esposito, 2014; Selcuk Can et al., 2014; Solár et al., 2016).

Efforts towards integrated nature conservation are reflected in the concept of UNESCO $\mathrm{MaB}$ biosphere reserves (BR). At present, a biosphere reserve is considered to be an area where three basic missions are simultaneously met: (1) conservation of biological diversity/nature; (2) research, education and awareness raising; and (3) promotion of sustainable development (Jeník, 1996; UNESCO, 1996). Practical application of the biosphere reserve concept as a platform to be used for integrated nature conservation in large-scale protected areas can be considered both a practical challenge and still a vivid theme of discussion among researchers (e.g. Švajda, 2008; Özyavuz, Yazgan, 2010; Ludwig et al., 2012; Elbakidze et al., 2013; Onaindia et al., 2013; Petrova, 2014). In institutional terms, it is an open concept con- 
sidering all stakeholders (scientists in natural and social fields of expertise, different interest groups related to the conservation of nature as well as those aiming to foster development of the territory, representatives of administrative bodies, associations and local population) to be partners, and attempts to encourage them towards mutual cooperation and participation in the area management. Searching for a balance between the conservation of biodiversity and socio-economic and cultural development is concurrently seen as a dynamic process of innovation and learning through interaction, with participation being the key part of it (e.g. Lundvall, 1997; Kušová et al., 2008b).

In the Czech Republic, the particular types of protected areas are defined by the Act No. 114/92 Coll., the Nature and Landscape Conservation Act (Prchalová, 2010). Large-scale protected areas are classified into several categories. Biosphere reserves, however, have not been included among them. Practical application of the biosphere reserve concept therefore lacks legal enforceability. The status of biosphere reserve is generally perceived only as an internationally recognized certificate of quality, assigned to the areas already protected by the Czech legislation (Urban, 2006; Stoll-Kleeman, O'Riordan, 2017). This ambiguity leads to the situation where state nature conservation bodies have only a very limited space to manoeuvre in implementing this concept in practice (Kušová et al., 2008a). On the other hand, the legislative 'vacuum' opens space for local initiatives and may thereby encourage the establishment of local groups that can pragmatically use this concept for promoting their interests. The fact that the biosphere reserve is defined as a concept, i.e. as the sum of principles wherein the only requirement is that the principles be 'tailored' to the given area (UNESCO, 2008), opens a wide range of possibilities, including institutional forms, used for application of the concept in practice. ${ }^{11}$ In-situ application of the biosphere reserve concept can be interpreted as a process that attempts to design a sustainable landscape (e.g. Antrop, 2006; Kušová et al., 2008a) which can only be achieved based on a broad participation of all partners in the territory of interest.

In this context, the objective of the paper is to demonstrate practical application of action research in the process of step-by-step institutionalization of the Sumava Biosphere Reserve, Czech Republic, as a complement to the state-conducted nature conservation. By doing so, the paper aims to contribute to the still ongoing debate in landscape ecology concerning biosphere reserves as a conceptual frame and research field (e.g. Stoll-Kleeman, O’Riordan, 2017).

\section{Model area, material and methods}

Šumava Mountains is the forested border mountain range located in southwest Bohemia. It can be considered a historically cultural landscape (Fig. 2) that underwent a highly dynamic development in the period after Second World War. The attempts to harmonize nature conservation and local development have been existing there for a long time (e.g. Gorner et al., 2012; Křenová, Vrba, 2014). Large-scale nature conservation has been applied to this area since 1963, when the Šumava Protected Landscape Area (PLA) was declared, the largest in the Czech Republic.

\footnotetext{
${ }^{1}$ Since 2003, three institutional models of the biosphere reserve were existing in the Czech Republic. The first model was based on exclusive association of the biosphere reserve with the state administration of a particular protected landscape area (the Krrivoklátsko BR, the Třeboňsko BR, and it was also the starting position in the Šumava BR). The second model was implemented as a cooperation between the administration of a particular protected landscape area and a non-profit organisation implementing the biosphere reserve agenda (the Krkonoše and Bílé Karpaty BRs). The third model was represented by the Lower Morava BR and takes the form of a public benefit organisation.
} 


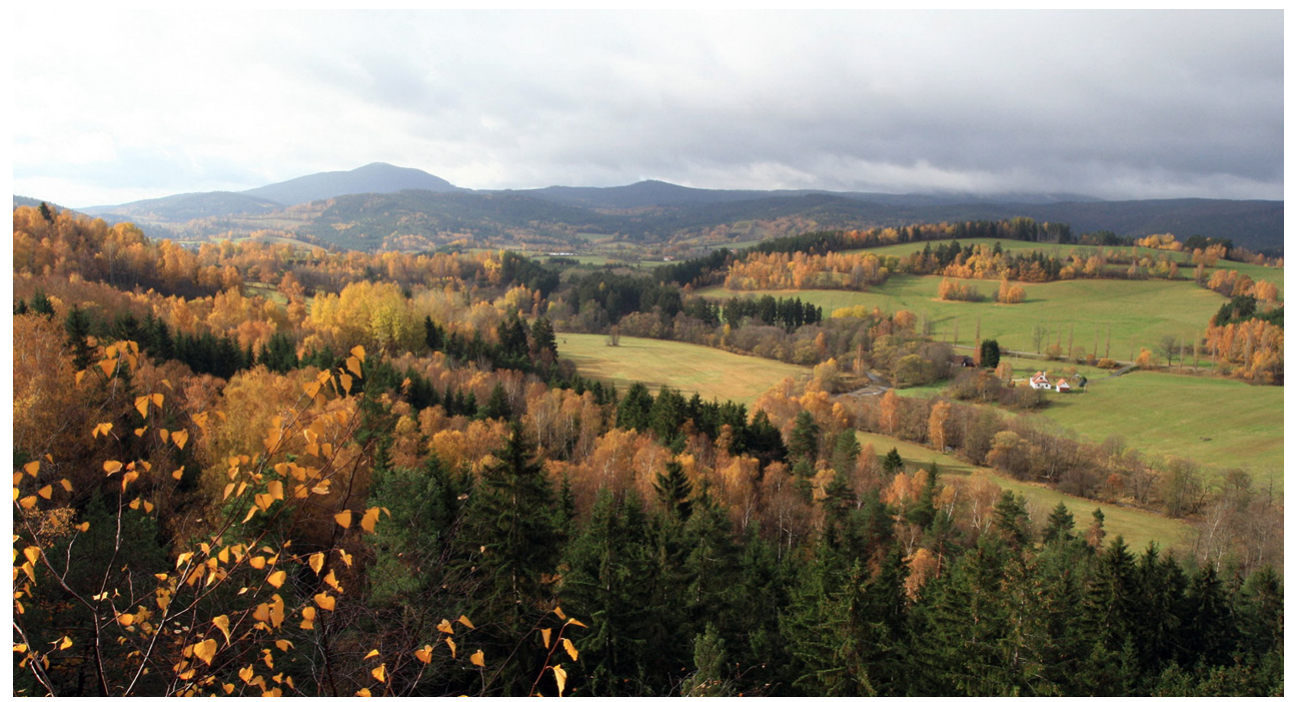

Fig. 2. Panoramic view of the Šumava Mts. landscape, demonstrating its cultural character (Blanice valley viewed from the Zábrdská Rock). Photo: Vladimír Silovský.

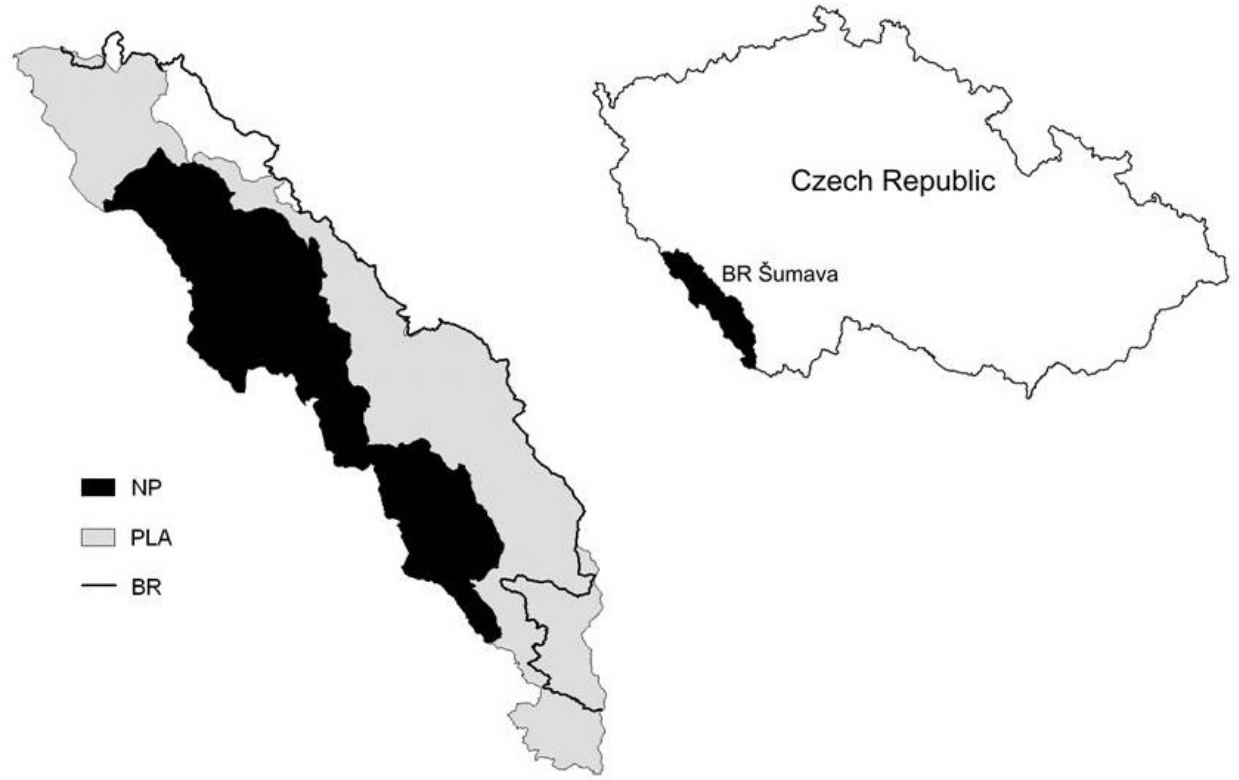

Fig. 3. Schematic Map of the Šumava Biosphere Reserve. Source: authors.

Notes: NP = National Park; PLA = Protected Landscape Area; BR = Biosphere Reserve. 
$\mathrm{T}$ a b $1 \mathrm{e}$ 1. List of projects realised by the authors in the territory in the period 1995-2013, directly related to the process of the Šumava Biosphere Reserve institutionalisation.

\begin{tabular}{|l|l|l|}
\hline No. & Project identification & Period \\
\hline 1 & $\begin{array}{l}\text { Sustainable development strategy for the Šmava Biosphere reserve. UNEP-GEF project } \\
\text { on Biodiversity conservation in the Czech Republic, funded by the World Bank. }\end{array}$ & $1995-1997$ \\
\hline 2 & $\begin{array}{l}\text { Carrying capacity and revenue mechanisms for the Šmava Biosphere reserve, UNEP- } \\
\text { GEF project on Biodiversity conservation in the Czech Republic, funded by the World } \\
\text { Bank. }\end{array}$ & $1995-1997$ \\
\hline 3 & $\begin{array}{l}\text { Participative management of protected areas - key to minimize conflicts between nature } \\
\text { conservation and socio-economic development of local communities, funded by the Min- } \\
\text { istry of the Environment of the Czech Republic. }\end{array}$ & $2003-2005$ \\
\hline 4 & $\begin{array}{l}\text { Conservation and Sustainable Use of Biodiversity through Sound Tourism Development } \\
\text { in Biosphere Reserves in Central and Eastern Europe. ('Tourism for Nature'), funded by } \\
\text { the UNEP-GEF. }\end{array}$ & $2005-2008$ \\
\hline 5 & $\begin{array}{l}\text { PANet 2010 - Managing Functional Networks of Protected Areas, funded by the Interreg } \\
\text { III B CADSES. }\end{array}$ & $2006-2008$ \\
\hline 6 & $\begin{array}{l}\text { VITAL LANDSCAPES - Valorisation and Sustainable Development of Cultural Land- } \\
\text { scapes using Innovative Participation and Visualisation Techniques, funded by the Inter- } \\
\text { reg CENTRAL EUROPE. }\end{array}$ & $2010-2013$ \\
\hline 7 & $\begin{array}{l}\text { Protected Areas - Social Deal on Nature Conservation, funded by the Czech Science } \\
\text { Foundation. }\end{array}$ & $2011-2013$ \\
\hline
\end{tabular}

Source: authors.

Granted by the biosphere reserve (BR) status in 1990, this area gained an internationally recognized certificate of 'nature quality'. In 1991, the most valuable natural part of the area was declared as the Šumava National park (NP) (Fig. 3).

The Selection of the Šumava Biosphere Reserve for our case study was supported primarily by two facts. Firstly, potential niche of the biosphere reserve in the life of the region was articulated already in the mid-1990s and potential consensual economic activities such as ecological agriculture, forestry and sound tourism were suggested (Jeník, Price, 1994; Price, 1996).

Twenty five years of its existence was then considered as the period long enough to reveal developmental trends. Secondly, the relationship between local people and nature conservation bodies in the Šumava Mts. has been in focus of our research since 1995. The general objective of the research - integrated nature conservation - was framed to address three themes: (i) quality of life of people living in protected area, (ii) social acceptance of nature conservation measures and (iii) institutionalization of biosphere reserve. The longitudinal research had an iterative character fitting the scheme of participatory action research (McTaggert, 1991; Kemmis, 1988) in which local people were involved as members of research team and took part in both the process of research objectives formulation, action taking and reflection of project outputs (see Fig. 1). The reflection was always built on information gained by a combination of quantitative and qualitative methods of data collection and processing (Kušová et al., 2008a, 2009). Following the scheme, we combined application projects as interventions triggering changes and scientific projects for evaluating and theoretically reflecting these changes. The recurring intervention-reflection/learning cycle was conducted during the years 1995-2013 (Table 1). ${ }^{2}$

The paper accentuates the process of institutionalization of the Šumava biosphere reserve. The process was described by use of qualitative research methods that primarily exploited data having a non-numerical character. Single-case case study method (Odell, 2004; Hendl, 2008) was applied as the format of narration. Qualitative case study methodology provides tools for researchers to study complex phenomena within their contexts. When the approach is applied correctly, it becomes a valuable method for research to develop theory, evaluate programmes, and

${ }^{2}$ At the beginning, the projects were affiliated with the Academy of Sciences (Institute of Landscape Ecology, renamed later on to the Institute of Systems Biology and Ecology), the last two with the University of South Bohemia, Faculty of Agriculture. 
develop interventions. The case was bounded as the process of the Šumava Biosphere Reserve institutionalization, taking place over the period 1991-2016. The scheme of action research was applied as the main interpretative frame. As the variable, institutional model of BR was defined with three levels of quality: BR as a part of the organisational scheme of the Šumava NP and PLA Administration under the condition that the administration had a dominant role in the territory; BR still a part of the organisational scheme of the administration, factually, however manifested as a network of projects and associated partners under the condition of the administration being a partner in the network, and BR based on the model of shared responsibility of the territory, under the condition that BR became a part of the organisational scheme of the Regional Development Agency Šumava. The necessary information was obtained from secondary analysis of interim and final reports of the projects mentioned in the Table 1 and selected research publications of the authors, referred in the text.

\section{Results and discussion}

UNEP-GEF Biodiversity Conservation Project for the Czech Republic was approved in 1994. The general objective of the project was to support integrated biodiversity conservation in the country in its transition from centralized to a democratic system of governance. Among other activities, regional conservation approaches, which would establish systematic cooperation with the resource using public around the strictly protected areas, were expected to be developed (World Bank, 1994). We entered the territory (and the situation) in mid-1990s, financially supported by the two subprojects of the above-mentioned project (projects No. 1 and 2 in the table). The Šumava NP and PLA Administration became our client. The aim was to analyse the present socio-economic situation in the region and to identify social positions of local and regional key stakeholders, including state nature conservation bodies, as viewed by general public as well as by key local personalities.

Due to the transformation of the national economy, from centrally planned to marketdriven, productive agriculture, traditionally present in the area, was undergoing rapid decline and was expected to be transformed into landscaping of some kind, sustaining the cultural character of the Šumava landscape, image of which was recognized as the main attractor for tourists and amenity migrants. In parallel, environment-friendly tourism was viewed by local elite as well as by general public to become the backbone of local economy (Těsitel et al., 1997; 1999; 2003; 2007; Bousset et al., 2007). The potential of environment-friendly tourism to bridge nature conservation interests and local economic raise was later on embodied into the Concept of Sustainable Tourism in the Šumava Mts., strategic document initiated by the Regional Development Agency Šumava (RDAŠ), but developed in the modus of cooperation among all key local stakeholders, including NP and PLA authorities.

Two principal players were identified in the territory, Administration of the NP and PLA, and RDAŠ. The Šumava NP was perceived as the champion, having the most powerful 'negotiating position'. As such it had a chance to play the role of a social entrepreneur (Garfoli, 1992), pushing forward the idea of integrated nature conservation in the territory (Bartoš et al., 1998). It was natural then, that the biosphere reserve became an organisational part of the NP and PLA Administration. However, the Administration did not take the momentum and was behaving in a rather arrogant way towards the other stakeholders in the territory, trying to apply people-exclusive model of nature conservation. It was negatively perceived at that time e.g. by representatives of local municipalities, who identified communication with the NP Administration and way by which it implemented the Nature Conservation Law as two 
among main obstacles for the territory development, along with lack of financial sources and socio-demographic structure of local inhabitants (Fig. 4).

Such kind of behaviour of state mandated nature conservation bodies was diagnosed to be more general problem at that time, rather than exception. Similar situation was identified in another three Czech biosphere reserves: BR Křivoklátsko, BR Šumava and BR Třeboňsko, institutionally represented by respective administrations of protected areas (project No. 3 ). State administration with its bureaucratic nature and rigid hierarchical structure appeared to fail in creating the appropriate conditions for the application of the third function of biosphere reserve - support of sustainable development (Kušová et al., 2005a,b, 2006, 2008a,b; Těšitel et al., 2005a,b). Lessons learned from the previous projects were evaluated and the client changed, which ultimately led to the situation that since that time, outputs of all the following projects were supposed as owned by the territory of the Šmava Biosphere Reserve as a whole, in practical terms, by locally operated institutions, associations, NGOs and en-

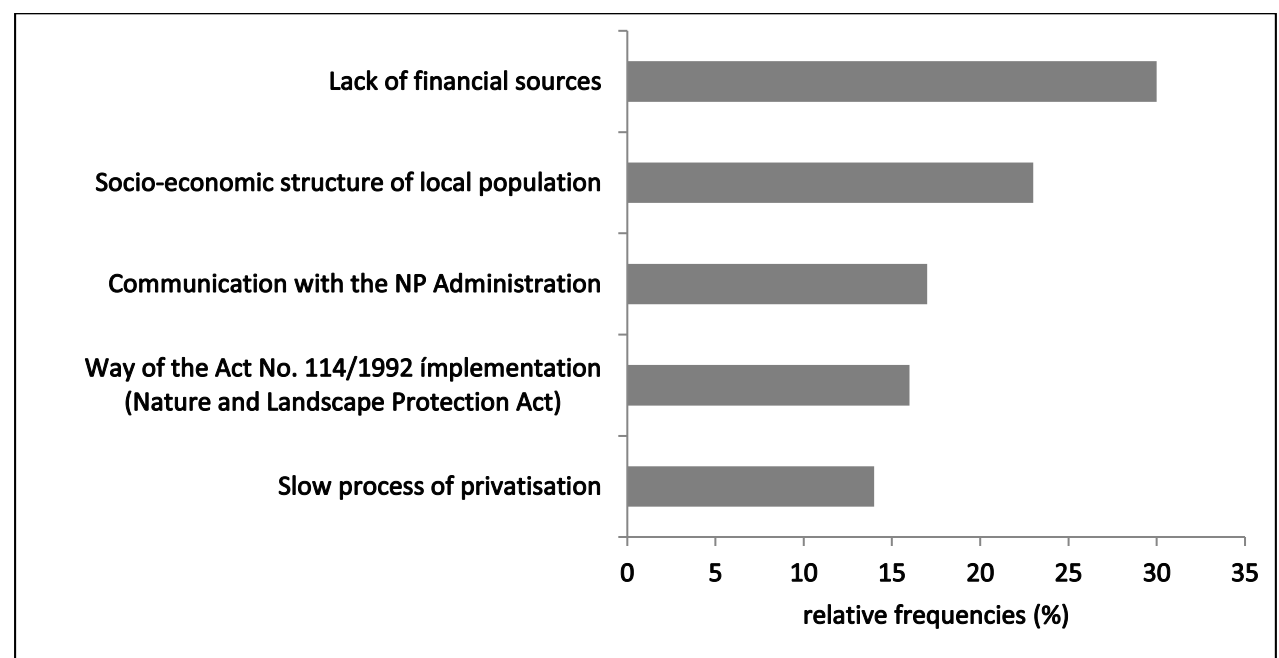

Fig. 4. Critical points in the territory development, identified by representatives of municipalities lying in the Protected Landscape Area in the nineties of the last century $(\mathrm{N}=63)$. According to Bartoš et al. (1998).

gaged key personalities, both private and public. Under these circumstances, we attempted to complement the existing bureaucratic model of the Šumava Biosphere Reserve with another one based on horizontal network structure, where principles of equality, voluntary cooperation and shared management are the building mechanism, with main link being mutual trust between all the stakeholders (e.g. Lagendijk, Cornford, 2000). The attempt was supported by two in-parallel running projects (projects No. 4 and 5). The Tourism for Nature project was de facto a 'manual' suggesting sound tourism to demonstrate the possibility of implementation of the 'nature conservation through its sustainable use' model into practice. The PANET 2010 project was then a scientific reflection of the implementation process. 
Activities taking during the Tourism for Nature project were derived from the Concept of Sustainable Tourism in the Šmava Mts, the outcome of the earlier UNEP-GEF project. They were nine interlinked activities, suggested by local stakeholders as the most important support for sound-tourism-based development of the territory. The portfolio of the project combined activities having very practical outputs with those that yielded strategic planning materials. 'Establishment of a System of Cross Border Tourist Trails', 'Training of Local Guides' (Fig. 5) and 'Identification of a Potential of the Šumava Biosphere Reserve for New Touristic Activities' could be seen as the most practical outputs of the project, having immediate impact on the territory. Improvement of small-scale tourist infrastructure, supported by the 'System of Financial Incentives', had a form of

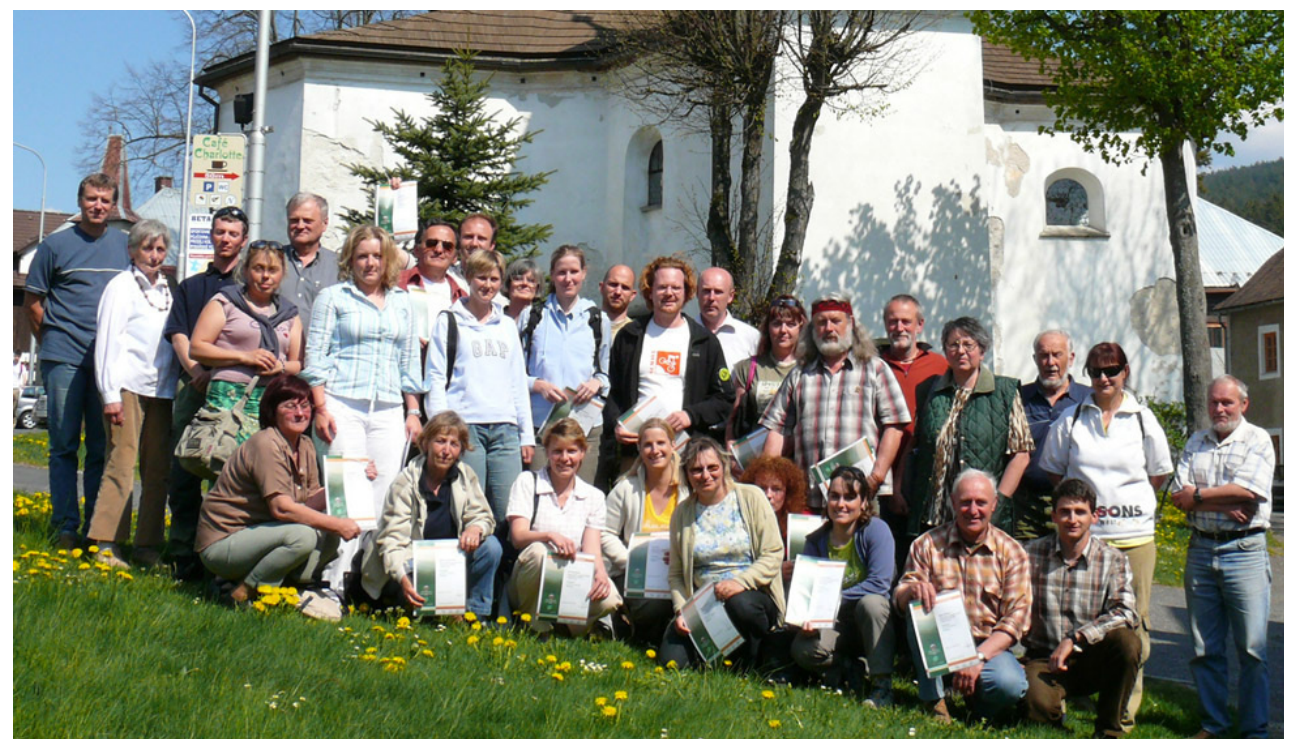

Fig. 5. Participants of the first 'Local guides' training course with their certificates, village of Železná Ruda, April 2007. Photo: Vladimír Silovský.

local grant scheme. 'System of Certification of Local Products and Services' was then aimed to facilitate the process of sound commodification of local area's natural and cultural capital.

Among the strategic activities we can count participation of the project in preparation of the 'Concept of Sustainable Tourism Development in the Šumava Region', 'Institutional Analysis of the Šumava Biosphere Reserve' and designing of an electronic 'Database on Cultural Heritage of the Šumava Biosphere Reserve'. Establishment of a platform for information exchange among local mayors, representatives of nature conservation authorities and other key stakeholders became an inseparable part of the project, manifested in the form of series of round tables and training courses (Kušová et al., 2008b). 
The broad scope of the project put together the bunch of mutually cooperating partners, both locally rooted and ex-territorial, in jointly accomplishing particular activities: Šumava NP Administration, Šumava Regional Development Agency, Institute of Systems Biology and Ecology AS CR ${ }^{3}$, NEBE ltd. and Regional Environmental Centre. The project as a whole was managed by the Project Steering Committee, composed of local and regional key stakeholders. The endeavour to achieve the locally defined and mutually agreed upon outputs lead to what could be said a change in perspective from inter-institutional to inter-personal. Working together for some time, representatives of the above-mentioned institutions gradually ceased pushing forward official doctrines of 'their institutions'. The communication started to be based primarily on their personal relations built on mutual trust among human beings. The contribution of the project, therefore, can by expressed not only in terms of its official outputs themselves, but primarily in terms of its 'by-product'- supporting, if not starting the process of the informal local communication platform building in the territory (Kušová et al., 2008b, 2009; Těšitel, Kušová, 2010; Zelenka et al., 2013).

The network-like structure, however, was truly project(s)-based in terms of financial support. New projects were needed, in order to keep this network alive after the Tourism for Nature project was completed. The fortunate situation of having a complex project or several cooperating ones did not repeat, however. The team broke up, and individual members started to apply for grants individually. The project-based structure appeared volatile. Therefore, more stable institutional structure was searched for. Financially supported by the application project VITAL LANDSCAPES, (project No. 6), we came to the model based on a clearly defined cooperation between the two key stakeholders in the area - Šmava NP and RDAS - in the application of the biosphere reserve concept in practice. The Memorandum of Understanding, negotiated already within the previous project, was signed by both parties, which finally installed the model of shared responsibility with clearly defined 'division of labour' between the partners. On this basis, Administration of National Park and Protected Landscape Area became the guarantor for the natural pillar, i.e. biodiversity conservation, nature-oriented research and environmental education, while the Regional Development Agency guaranteed the socio-economic pillar, i.e., conservation of cultural diversity, environment-friendly development of the territory, socio-economic research and general educational and development projects. In this institutional model, the biosphere reserve became an organizational part of the Šumava Regional Development Agency.

This model introduced an entirely new and not quite trivial situation for both the National Park Administration and the Development Agency. It introduced a challenge for the people working in these institutions, as they were required, among other things, to identify themselves with the newly established institution, whose activities only partially overlapped with the activities traditionally performed by their 'home' institutions. Under this scheme, the Administration of National Park and Protected Landscape Area 'lost' its position of the leader, it used to have and became a 'mere' partner. In addition, development activities were more balanced with those related to nature conservation in the new organizational scheme compared to the situation when BR was part of state administration in the protected area. The very concept of biosphere reserve, however, appeared to have a great potential to calm down the situation since it was 'coined in the

\footnotetext{
${ }^{3}$ At that time, the authors were staff members of the Institute.
} 
workshop' of nature conservation. In this context, it was easier for the representatives of state administration of nature conservation to accept the new role of a partner without having a feeling that they "lost a face" in discussions about the development of the region (Kušová, Těšitel, 2014; Těsitel et al., 2014). The process starting with the biosphere reserve being an organisational part of the state administration, through building partnerships by use of flexible network of projects and associated partners up to the reaching the model of shared responsibility for the commonly occupied territory, was then scientifically reflected within the last project in Table 1 (project No. 7).

At the end of the story, we can suggest that biosphere reserve concept manifests qualities of a post-modern fluid structure (Bauman, 2002). If separated from state-based financing, it was used expediently only, in situations when project funds were available, allowing implementation of various activities. The outputs and activities of these projects, if proved to be promising investments, were subsequently enacted as a part of the standard portfolio of services provided by partners involved. For example, the system of 'Local Guides' was adopted by the Administration to National Park and Protected Landscape Area and included in its regular portfolio of services provided for the public and further enriched by providing 'Guides to the wilderness' to the public. In the case of RDAŠ, the certification system 'Šumava-originální produkt ${ }^{\circledR}$ (Šumava original product), originally promoting exclusively local products, was expanded to cover certification of services related to environmentfriendly tourism. The system was further developed and nowadays, it includes as well 'Certification of Experiences'. The NEBE Ltd. extended the original database on cultural heritage on the territory of the Šumava BR up to the form of web portal REGIOSKOP that provides information on cultural heritage on the whole Czech-Bavaria-Saxony borderland. ${ }^{4}$

Nevertheless, thanks to the activities realized, the term 'biosphere reserve' was incorporated into regional strategic landscape planning documents, e.g. the Masterplan Šmava ${ }^{5}$.

As mentioned earlier, the biosphere reserve concept represents an innovative approach in nature conservation (Kušová, Těšitel, 2016b), based on the principle of social inclusion and the conservation of biodiversity through its sustainable use. It is defined as a bottom-up activity pursuing to find a locally acceptable balance between nature conservation interests and socio-economic aspiration of local population. This objective was defined legislatively, by the Act No. 114/1992 Coll., the Nature and Landscape Conservation Act, that complemented the exclusive approach to nature conservation with an inclusive one. Thus, it defined the requirement that not only the state but also the localities in question be involved in the nature conversation, in the form of co-management of protected areas. ${ }^{6}$ Although the objective was clearly defined, the Administration of NP and PLA, as a lower-ranking element in the hierarchical model of the state administration, kept the logic of functioning of bureaucracy (Keller, 2007) and waited for clear and uniform rules that would come from above-rank to regulate its behaviour. However, in the 1990s the use of new concept had to be learned by the Minis-

\footnotetext{
${ }^{4}$ http://www.regioskop.eu/

${ }^{5}$ http://www.npsumava.cz/gallery/16/4926-masterplan_sumava_fin.pdf

${ }^{6}$ This tendency is Europe- and World-wide, as can be documented e.g. by the European Landscape Convention, effective since March 2004. It specifies the requirement to integrate participatory principles into landscape in signatory countries, (Council of Europe, 2000). Nowadays, these principles have become guiding ideas of the Agenda 2030 (United Nations, 2015a) and Sustainable Development Goals (United Nations, 2015b).
} 
try of the Environment itself. Therefore, the entire system was lacking operational rules for coping with the new situation. The UNESCO MaB biosphere reserve concept was therefore used as a training of some kind, where the administration could practice and play the role of a partner. The use of the model in the Šmava Mts. was facilitated by the fact that this activity was initially supported by international projects. Later, the Ministry began to implement its own projects, which allowed the Administration of NP and PLA to test the application of participatory methodologies of Local Agenda 21 (LA21) when communicating with other users of the area. As an example of such a project, the Landscape Integrated Development Plan for the Sumava NP Region (in Czech named KIPR) ${ }^{7}$, valid for the period of 2011-2020, can be used (Kopp, 2014). Today, state administration in nature conservation in the Sumava Mts. applies (or at least tries to apply) the integrated management of large-scale protected areas as a standard. Hence, the biosphere reserve concept was replaced with the rules introduced directly within the vertical structure of state administration, hence internalized by the state administration (Kušová, Těšitel, 2016a).

In this situation, activity of the Šumava Biosphere Reserve began to be focused on the promotion and implementation of projects related to the sound use of local and regional natural and cultural heritage, not necessarily directly related to nature conservation, but relying primarily on the principles of landscape conservation through its sustainable use. It can be documented e.g. by the project 'Šumava Biosphere Reserve, a good place for living', cofunded by the European Union, Cross-border Cooperation Programme Objective 3 Czech Republic - Free State of Bavaria 2007-2013, which aims to enable a comprehensive promotion of the Šumava Biosphere Reserve in the region, including leaflets, film and brochures ${ }^{8}$.

Nevertheless, the model of shared responsibility, and hence division of labour between the two constitutive partners, National Park and Regional Development Agency, sustained the operations for the care of Šmava Mts. landscape, as manifested in currently running projects. The Agency guarantees the projects of Certification of regional products ${ }^{9}$; the project ViaNova (maintaining part of the pilgrimage route connecting Bavarian Vilshofen with Czech Saint Berg ${ }^{10}$ ) and the project 'White trail' - aimed at maintaining of system of crosscountry trails ${ }^{11}$. National Park, complementary, guarantees application of the European system of NATURA 2000, including management of Sites of Community Importance on the territory of the Šumava Biosphere reserve ${ }^{12}$.

\section{Conclusion}

In Europe, integrated nature conservation is realised through biosphere reserves and national parks (Hirschnitz-Garbers, Stoll-Kleemann, 2011). In this sense, the missions of national park and biosphere reserve were defined in a similar way. For example, Act No. 114/92 Coll. mandated the establishment of the National Park Council, in which the self-government

\footnotetext{
${ }^{7}$ http://www.npsumava.cz/gallery/22/6738-krajinny_integrovany_plan_rozvoje_fin.pdf

${ }^{8} \mathrm{http} / / /$ www.br-sumava.cz/data/File/dokumenty/brochure_br_en.pdf

${ }^{9} \mathrm{http}: / /$ www.br-sumava.cz/znaceni-sumava-originalni-produkt/

${ }^{10} \mathrm{http}: / /$ www.br-sumava.cz/vianova/

${ }^{11} \mathrm{http}: / /$ www.br-sumava.cz/bila-stopa/

${ }^{12} \mathrm{http} / / /$ www.br-sumava.cz/natura-2000-v-br/
} 
of municipalities located on the National Park territory, was properly represented. Consequently, at the beginning of nineties of the last century there were theoretically two institutional instruments in the Šmava Mts. available to implement the model of integrated nature conservation: national park and biosphere reserve. Neither of them was used practically for this purpose at that time, however. National park, as a representative of state administration, still continued to practice centralistic model of management and decision making, characterized by the dominance of state power. Biosphere reserve, on the contrary, was ahead of its time. The idea of horizontal (social) networks as organizational structures was far from being understood, let alone practiced at that time. The 'delay' in real application of the integrated nature and landscape conservation in the Šmava Mts. can be explained by referring to the fact that most of the existing participatory models were based on the experience obtained in an environment of relatively stable democracies (Hall, 2000; Kluvánková-Oravská, Chobotová, 2010). These experiences were lacking in 1990s in the Czech Republic and de facto in countries of Central and Eastern Europe in general.

When reflecting back on the process of institutionalization of the Šumava Biosphere reserve, we can suggest its present model emerged primarily thanks to the step-by-step process of a 'permanent jointly conducted experiment' that followed the spiral scheme of action research, in which outputs of one implementation project served as a starting point to formulate, and subsequently realize the follow-up projects. Effective communication with a client is considered an important aspect of action research as it influences profoundly transfer of theoretical outputs into their practical use. In this respect, the Administration of the Šumava NP and PLA appeared to fail as a client in the mid-1990s, mostly because of its low motivation to communicate with the others in the region. Therefore we started to rely on a much broadly defined one, which at the same time fitted more closely to the definition of a client as it was suggested for biosphere reserves since the Seville Strategy. As the local community was engaged in the whole process, lessons learned from it became a part of local social and cultural capital, which since can be considered important endogenous developmental potential of the region. At the same time, being 'within the system' enabled us, researchers, to reflect more adequately local knowledge, which otherwise could not be obtained and use it for more comprehensive understanding of functioning of local socio-ecological system.

\section{Acknowledgements}

The study is an output of the project GAČR P404/11/0354: 'Protected Areas - Social Deal on Nature Conservation'. We also would like to express many thanks to Dr. Jan Květ, the chair emeritus of the Czech national MaB Committee, for his kind comments on the manuscript.

\section{References}

Antrop, M. (2006). Sustainable landscapes: contradiction, fiction or utopia. Landsc. Urban Plann., 75(3-4), $187-197$. DOI: 10.1016/j.landurbplan.2005.02.014.

Bartoš, M., Kušová, D. \& Těšitel J. (1998). Integrated endogenous regional development concept and the role of Šumava National Park administration. Silva Gabreta, 2, 385-394.

Bauman, Z. (2002). Tekutá modernita. Praha: Mladá fronta.

Becker, C. \& George B.P. (2011). Rapid trail transit and tourism development in the United States. Tourism Geographies, 13(3), 381-397. DOI: 10.1080/14616688.2011.570779. 
Berg, B.L. (2004). Qualitative research methods for the social sciences. Boston: Pearson Education.

Bousset, J.P., Skuras, D., Těšitel, J., Marsat, J.P., Petrou, A., Pantziou, E.F., Kušová, D. \& Bartoš M. (2007). A decision support system for integrated tourism development: Rethinking tourism policies and management strategies in the Czech Republic, France and Greece. Tourism Geographies, 9(4), 387-404. DOI: 10.1080/14616680701647576.

Council of Europe (2000). European Landscape Convention. Florence: Council of Europe. On-line available on http://www.mzp.cz/C1257458002F0DC7/cz/evropska_umluva_o_krajine_smlouva/\$FILE/OZV_anglicky_ text_EoUK_20120125.pdf. Downloaded 02.06. 2017

Elbakidze, M., Angelstam, P., Sandström, C., Stryamets, N., Crow, S., Axelsson, R., Stryamets, G. \& Yamelynets T. (2013). Biosphere Reserves for conservation and development in Ukraine? Legal recognition and establishment of the Roztochya initiative. Environ. Conserv., 40(2), 157-166. DOI: 10.1017/S0376892912000434.

Elden, M. \& Chisholm R.F. (1993). Emerging varieties of action research: Introduction to the special issue. Human Relations, 46(2), 121-142. DOI: 10.1177/001872679304600201.

Garfoli, G. (1992). Endogenous development and Southern Europe: and introduction. In G. Garfoli (Ed.), Endogenous development and Southern Europe. Averbury: Aldershot.

Ghimire, K. \& Pimbert M. (1997). Social change and conservation: an overview of issues and concepts. In K. Ghimire \& M. Pimbert (Eds.), Social change and conservation: Environmental politics and impacts of national parks and protected areas. London: Earthscan Publications.

Gorner, T., Najmanova, K. \& Cihar M. (2012). Changes in local people's perceptions of the Šumava National Park in the Czech Republic over a ten year period (1998-2008). Sustainability, 4(6), 1354-1370. DOI: 10.3390/su4061354.

Habibah, A., Mushrifah, I., Hamzah, J. E.A.C., Buang, A., Toriman, M.E., Selvadurai, S. \& Zaimah R. (2013). Placemaking of ecotourism in Tasik Chini: From exploratory to the contemporary biosphere reserve. Asian Social Science, 9(6), 84-95. DOI: 10.5539/ass.v9n6p84.

Hadwen, W.L., Boon, P.I. \& Arthington A.H. (2012). Aquatic ecosystems in inland Australia: tourism and recreational significance, ecological impacts and imperatives for management. Mar. Freshw. Res., 63(4), 325-340. DOI: $10.1071 / \mathrm{MF} 11198$.

Hall, D. (2000). Identity, community and sustainability: Prospects for rural tourism in Albania. In D. Richards \& D. Hall (Eds.), Tourism and sustainable community development. London: Routledge.

Hayes, T. (2006). Parks, people and forest conservation: An institutional assessment of the effectiveness of protected areas. World Development, 34(12), 2064-2075. DOI: 10.1016/j.worlddev.2006.03.002

Hendl, J. (2008). Kvalitativní výzkum: základní teorie, metody a aplikace. Praha: Portál.

Hirschnitz-Garbers, M. \& Stoll-Kleemann S. (2011). Opportunities and barriers in the implementation of protected area management: A qualitative meta-analysis of case studies from European protected areas. Geographical Journal, 177(4), 321-334. DOI: 10.1111/j.1475-4959.2010.00391.x.

Holling, C.S., Carpenter, S.R., Broclt, W.A. \& Gunderson L.H. (2002). Discoveries for sustainable futures. In L.H. Gunderson \& C.S. Holling (Eds.), Panarchy: understanding transformations in systems of humans and nature. Washington DC: Island Press.

Jeník, J. \& Price M.F. (1994). Biosphere Reserves on the Crossroads of Central Europe. Praha: Empora.

Jeník, J. (1996). Biosférické rezervace České republiky: př́roda a lidé pod záštitou UNESCO. Praha: Empora.

Keller, J. (2007). Sociologie organizace a byrokracie; druhé vydání. Praha: SLON.

Kemmis, S. (1988): The action research reader. Victoria, Australia: Deakin University.

Kluvánková-Oravská, T. \& Chobotová V. (2010). Inštitúcie a ekosystémové služby v demokratickej a trhovej spoločnosti. Životné Prostredie, 44(2), 84-87.

Kopp, J. (2014). Strategické plánování udržitelného rozvoje velkoplošných chráněných území. Trendy v Podnikání, 4(4), 58-66.

Křenová, Z. \& Vrba J. (2014). Just how many obstacles are there to creating a national park? A case study from the Šumava National Park. European Journal of Environmental Sciences, 4(1), 30-36. DOI: 10.14712/23361964.2015.2.

Kušová, D., Těšitel, J., Matějka, K. \& Bartoš M. (2005a). Nature conservation and socio-economic development in selected protected areas. Ekológia (Bratislava), 24(Suppl. 1), 109-124.

Kušová, D., Těšitel, J. \& Bartoš M. (2005b). Medial image of the relation between nature conservation and socioeconomic development in selected protected areas. Silva Gabreta, 11(2), 123-133.

Kušová, D., Těšitel, J., Matějka, K. \& Bartoš M. (2006). Socio-economic conditions in selected biosphere reserves. Silva Gabreta, 12(3), 157-169.

Kušová, D., Těšitel, J., Matějka, K. \& Bartoš M. (2008a). Biosphere reserves - an attempt to form sustainable landscapes (A case study of three biosphere reserves in the Czech Republic). Landsc. Urban Plann., 84(1), 38-51. DOI: 10.1016/j.landurbplan.2007.06.006 
Kušová, D., Těšitel, J. \& Bartoš M. (2008b). Biosphere reserves - learning sites of sustainable development? Silva Gabreta, 14(3), 221-234.

Kušová, D., Těšitel, J. \& Bartoš M. (2009). Biosphere reserves as learning sites for sustainable development (a case study of the Czech Republic). In L.R. Elling (Ed.), Social development. New York: Nova Publishing.

Kušová, D. \& Těšitel J. (2014). Social perception of nature conservation in protected areas (Czech Republic case). Silva Gabreta, 20(1), 41-54.

Kušová, D. \& Těšitel J. (2016a): The Šumava Biosphere Reserve - historical reflection on institutional arrangements. Silva Gabreta, 22(1), 99-109.

Kušová, D. \& Těšitel J. (2016b): Biosférická rezervace Šumava - inovativní nástroj integrované ochrany přírody. Regionální rozvoj mezi teorií a praxí, 2, 88-103.

Lagendijk, A. \& Cornford J. (2000). Regional institutions and knowledge - tracking new forms of regional development policy. Geoforum, 31, 209-218. DOI: 10.1016/S0016-7185(99)00031-7.

Law, R., Leung, R. \& Buhalis D. (2009). Information technology applications in hospitality and tourism: A reviews of publications from 2005 to 2007. Journal of Travel and Tourism Marketing, 26(5-6), 599-623. DOI: $10.1080 / 10548400903163160$.

Lisi, F.A. \& Esposito F. (2014). Semantic web services for integrated tourism in the Apulia region. CEUR Workshop Proceedings, 1195, 178-193.

Ludwig, M., Grüninger, F., Rothfuss, E. \& Heurich M. (2012). Discourse analysis as an instrument to reveal the pivotal role of the media in local acceptance or rejection of a wildlife management project. A case study from the Bavarian Forest National Park. Erdkunde, 66(2), 143-156. DOI: 10.3112/erdkunde.2012.02.04.

Lundvall, B.Å. (1997). Information technology in the learning economy. Communications and Strategies, 28, 117-192.

McTaggert, R. (1991): Principles for participatory action research. Adult Education Quarterly, 41(3), 168-187. DOI: $10.1177 / 0001848191041003003$.

Odell, J.S. (2004). Case study methods in international political economy. In D.F. Sprinz \& Y. Wolinski-Nahmias (Eds.), Models, numbers and cases: Methods for studying international relations. Michigan: University of Michigan Press.

Onaindia, M., Ballesteros, F., Alonso, G., Monge-Ganuzas, M. \& Peňa L. (2013). Participatory process to prioritize actions for a sustainable management in a biosphere reserve. Environmental Science and Policy, 33, $283-294$. DOI: 10.1016/j.envsci.2013.05.012.

Özyavuz, M. \& Yazgan M.E. (2010). Planning of İgneada longos (flooded) forests as a biosphere reserve. J. Coast. Res., 26(6), 1104-1111. DOI: 10.2112/JCOASTRES-D-09-00065.1.

Paavola, J. \& Adger N.W. (2005). Institutional ecological economics. Ecological Economics, 53, 353-368. DOI: 10.1016/j.ecolecon.2004.09.017.

Petrova, S. (2014). Communities in transition: Protected nature and local people in Eastern and Cental Europe. Manchester: University of Manchester.

Prchalová, J. (2010). Zákon o ochraně přirody a krajiny a NATURA 2000. Úplné znění zákona s komentářem, judikaturou a provádécími predpisy. Praha: LINDE.

Price, M.F. (1996). UNESCO'S Man and the Biosphere (MAB) programme in the mountains of Central and Eastern Europe: past experiences and future possibilities. Silva Gabreta, 1, 289-298.

Selcuk Can, A., Alaeddinoglu, F. \& Turker N. (2014). Local authorities participation in the tourism planning process. Transylvanian Review of Administrative Sciences, 41, 190-212.

Solár, J., Janiga, M. \& Markuljaková K. (2016). The socioeconomic and environmental effects of sustainable development in the Eastern Carpathians, and protecting its environment. Pol. J. Environ. Stud., 25(1), 291-300. DOI: $10.15244 /$ pjoes/60177.

Stoll-Kleeman, S. \& O’Riordan T. (2002). From participation to partnership in biodiversity conservation: experience from Germany and South Africa. Society and Natural Resources, 15, 161-177. DOI: 10.1080/089419202753403337.

Stoll-Kleeman, S. \& O’Riordan T. (2017). The challenges of the anthropocene for Biosphere Reserve. Parks, 23(1), 89-100. DOI:10.2305/IUCN.CH.2017.PARKS-23-1SS-K.en.

Susman, G.I. \& Evered R.D. (1978). An assessment of the scientific merits of action research. Administrative Science Quarterly, 23(4), 582-603.

Švajda, J. (2008). Participatory conservation in a post-communist context: The Tatra national park and biosphere reserve, Slovakia. International Journal of Biodiversity Science and Management, 4(4), 200-208. DOI: 10.3843/ Biodiv.4.4:3.

Těšitel, J., Bartoš, M., Cudlínová, E., Heřman, M., Kušová, D. \& Zemek F. (1997). Sustainable development strategy for the Šumava Biosphere Reserve. Final report. České Budějovice: Institute of Landscape Ecology AS CR. 
Těšitel, J., Kušová, D. \& Bartoš M. (1999). Non marginal parameters of marginal areas. Ekológia (Bratislava), 18(2), 39-46.

Tešitel, J., Kušová, D. \& Bartoš M. (2003). Role of tourism in development of rural marginal areas (region Šumava Mts., Czech Republic). In J. Banski \& J. Owsinski (Eds.), Alternatives for European Rural Areas. Warsaw: European Rural Development Network, Institute of Agricultural and Food Economics, Institute of Geography and Spatial Organization, Polish Academy of Science.

Těšitel, J., Kušová, D., Matějka, K. \& Bartoš M. (2005a). Protected landscape areas and regional development (the case of the Czech Republic). In Z. Florianczyk \& K. Czapiewski (Eds.), Rural development capacity in Carpathian Europe. Warsaw: European Rural Development Network, Institute of Agricultural and Food Economics, Institute of Geography and Spatial Organization, Polish Academy of Science.

Těšitel, J., Kušová, D., Matějka, K. \& Bartoš M. (2005b). Lidé v biosférických rezervacích. České Budějovice: Institute of System Biology and Ecology AS CR.

Těsitel, J., Kušová, D. \& Bartoš M. (2007). Šetrný turismus v biosférických rezervacích - nástroj formování sití spolupráce (případová studie Biosférické rezervace Šumava). Klagenfurt: Government of Carinthia.

Těšitel, J. \& Kušová D. (2010). Biosphere reserves - suggested model of the institution of commons (Case study of the Šumava Biosphere Reserve). Journal of Landscape Ecology, 3(2), 73-89.

Těšitel, J., Kušová, D., Silovský, V. \& Matějka K. (2014). Biosphere reserve - platform to communicate nature conservation with local development (Šumava Mts., Czech Republic case). In J. Těšitel, B. Kolbmüller \& G. Stöglehner (Eds.), Vital landscapes. České Budějovice: NEBE.

Tress, B., Tress, G. \& Valk V.D. (2003). Interdisciplinary and transdisciplinary landscape studies - the Wageningen DELTA approach. In B. Tress, G. Tress, A. Valk \& G. Fry (Eds.), Interdisciplinarity and transdisciplinarity in landscape studies: Potential and limitations. Wageningen: DELTA series 2.

Troll, C. (1939). Luftbildplan und ökologische Bodenforschung. Zeitschrift der Gesellschaft für Erdkunde, Berlin.

United Nations (2015a). Transforming our World: The 2030 Agenda for Sustainable Development. On-line available on https://sustainabledevelopment.un.org/content/documents/21252030\%20Agenda\%20for\%20Sustainable\%20Development\%20web.pdf . Downloaded 02. 06. 2017.

United Nations (2015b). Sustainable Development Goals. On-line available on http://www.un.org/sustainabledevelopment/sustainable-development-goals/. Downloaded 02. 06. 2017.

UNESCO (1996): Biosphere Reserves: The Seville Strategy and the Statutory Framework of the World Network. Paris: UNESCO.

UNESCO (2008). The Madrid declaration. Paris: UNESCO.

Urban, F. (2006). Institutional and management frameworks in the Biosphere Reserve Šumava. Manuscript, study on behalf of ETE (Ecological Tourism in Europe). Bonn: ETE

World Bank (1994): Czech Republic Biodiversity Project. Global Environmental Facility, Report No. 11739-CZ.

Zelenka, J., Těšitel, J., Pásková, M. \& Kušová D. (2013). Udržitelný cestovní ruch - management cestovního ruchu v chránèných územích. Hradec Králové: Gaudeamus. 